\title{
Intraperitoneal Mesh Repair for Incisional Hernia
}

\author{
Fatma K. Al-Thubaity, MBBH, FRCS(I) and \\ Adnan A. Merdad, MBBCH, FRCS(C) \\ Department of Surgery, Faculty of Medicine \\ King Abdulaziz University, Jeddah, Saudi Arabia \\ drfatmasurgery2000@hotmail.com
}

\begin{abstract}
Seventy-three patients who had incisional hernia repair at two hospitals, a government and a private, from 2000 to 2005 were reviewed. Fifty-nine (80.8\%) patients were females and $52(71.2 \%)$ patients were Saudi. Five $(6.8 \%)$ patients had minor complications. Twenty-four (32.9\%) patients had polypropylene mesh while 49 (67.1\%) patients had vypro mesh, both types where fixed intraperitoneally using absorbable vicryl $2 / 0$ interrupted suture. No differences in complications, duration of surgery, or hospital stay between patients using either vypro or prolene mesh. Intraperitoneal mesh placement of incisional hernia is safe on short and long term follow-up. Vypro mesh compares favorably with prolene mesh. The authors encountered no enterocutaneous fistula and experienced only $2(2.7 \%)$ recurrences over one year.
\end{abstract}

Keywords: Repair of incisional hernia, intraperitoneal fixation, vypro or prolene mesh, complications.

\section{Introduction}

Incisional hernia occurs in $11-20 \%$ of laparotomy cases. They should be treated surgically because they grow in size and get symptomatic sooner or later, possibly leading to serious complications if they incarcerate or strangulate $^{[1]}$. A successful hernia repair should have low recurrence rate, less postoperative pain and complications ${ }^{[2]}$.

Correspondence \& reprint requests to: Dr. Fatma K. Al-Thubaity

P.O. Box 80215, Jeddah 21589 Saudi Arabia

Accepted for publication: 29 January 2007. Received: 5 October 2006. 
In literature, incidence of recurrence of primary repair of incisional hernias ranges from $31 \%-54 \%^{[3,4]}$. Use of prosthetic biomaterial (mesh) to buttress defect of incisional hernias, creating tension-free repair, showed to be superior to primary repair with reduction of hernia recurrence $(4 \%-24 \%)^{[1]}$. Mesh can be used as onlay graft, placed in subfascial extraperitoneal or intraperitoneal position. Animal experiments showed that synthetic mesh induced initial inflammatory reaction depending on chemical nature of implanted material, physical features and mechanical characteristics of implant ${ }^{[6]}$.

Multiple types of synthetic meshes are available ${ }^{[5]}$. They differ in their structure, material and resorption. Polypropylene (PP) mesh offers long-term stability, reasonable elasticity, permanent without tendency to degrade and induction of acute inflammation ${ }^{[7]}$. Vypro mesh characterized by reduction of PP weight, increase in pore size, has only $50 \%$ of permanent mesh component and associated with supplementary Polyglactin filaments to improve intraoperative handling during mesh placement $^{[8]}$. These features would contribute to lesser erosion risk ${ }^{[7]}$, less inflammatory reaction ${ }^{[9]}$, less abdominal adhesions ${ }^{[10]}$, and permits proper tissue integration through formation of a scar net instead of stiff scare plate $^{[9]}$.

Aim of this study was to describe the experience to repair incisional hernia using intraperitoneal mesh and compare clinical outcome, complications developed after using two different types of meshes prolene and vypro to determine whether enterocutaneous fistulas developed after incisional hernia repair.

\section{Material and Methods}

A retrospective review of patients' medical records $(n=73)$ who underwent incisional hernia repair with intraperitoneal placement of either PP $(n=24)$ or vypro mesh $(n=49)$ between (January 2000 December 2005) in Department of Surgery at King Abdulaziz University Hospital (KAUH) and Bakhsh Hospital, Jeddah, Saudi Arabia were made. Demographic data, previous hernias repair, associated comorbidity, mesh type, surface area, duration of surgery, hospital stay, follow-up, and postoperative complications were recorded. 
Patients were eligible for enrollment into study if they meet the following criteria: (a) Age was $\geq 18$-years-old; (b) Diagnosis of incisional hernia 9 to $225 \mathrm{~cm}^{2}$ in size; (c) Hernia was not primary; (d) Patient had no bowel obstruction, strangulation, peritonitis, perforation, cirrhosis; and (e) Patient had no local or systemic infection.

All patients had prophylactic antibiotic (second-generation cephalosporin). Operative technique used begins with midline incision. Hernia sac is dissected and opened carefully. Adhesions were removed from sac and edge of hernia, with dissection extending about 5 to $7 \mathrm{~cm}$ in all directions. Prolene or vypro mesh was then positioned intraperitoneally. In the initial 24 patients, PP mesh was used. Omentum was applied between bowel and mesh if possible. Mesh overlapped fascial defect by at least $3 \mathrm{~cm}$ circumferentially and fixed intraperitoneal with 4-6 interrupted vicryl 2/0 sutures in the corners of the mesh to prevent retraction and crumbling of the mesh. If possible, prosthesis is covered with remains of the resection sac or duplication of sheath of rectus muscles.

\section{Statistics Analysis}

Statistical analysis was carried out using the software, Statistical Package for Social Sciences (SPSS), Version 12. All data were expressed as numbers and percentage or mean $\pm \mathrm{SD}$. Difference between measured parameters was done using independent " $t$ " test. P-values $<0.05$ were considered to be significant.

\section{Results}

Seventy-three patients were reviewed 59 (80.8\%) were female. Age of participated patients ranged from 30.0-91.0 years (mean \pm SD, 48.9 \pm 12.2 years). Fifty-nine $(80.8 \%)$ patients had no medical illness. Prolene mesh was used on the initial $24(32.9 \%)$ patients then vypro mesh was used on $49(67.1 \%)$ patients. Table 1 showed demographic characteristics of the study patients.

Table 2 showed data comparing results of the two types of mesh used in this study. Type of previous operation, number of first time previous repairs were non-significantly differ in PP compared to vypro repaired operations $(\mathrm{p}>0.05)$. Percentages with postoperative 
complications were non-significant declined in vypro versus PP mesh repair operations $(97.9 \%$ vs. $83.3 \%$; $(p>0.05)$. In comparison of postoperative complications of prolene vs. vypro mesh (recurrence $(2.7 \%)$, wound sinus $(4.2 \%)$ and pulmonary embolism $(4.2 \%)$ were reported only with PP while, wound infection $(2.0 \%)$ was reported only with vypro). Mesh surface area, surgery, hospital stay, and follow-up duration were non-significantly elevated with PP compared to vypro mesh repaired operations.

Table 1. Demographic characteristics of patients.

\begin{tabular}{|lc|}
\hline \multicolumn{1}{c|}{ Variable } & Data $(\mathbf{n}=\mathbf{7 3})$ \\
\hline Age (years) & $48.9 \pm 12.2(30.0-91.0)$ \\
\hline Female:Male [n (\%)] & $59(80.8 \%): 14(19.2 \%)$ \\
\hline Medical Illness [n \%] & $59(81.8 \%)$ \\
No Medical Illness & $14(18.2 \%)$ \\
Medical Illness (Diabetes \& Hypertension) & \\
\hline Previous operations type [n (\%)] & $10(13.7 \%)$ \\
Hernia at Trocher Site (laparoscopy) & $63(86.3 \%)$ \\
Anterior Abdominal Wall Hernia & \\
\hline Type of mesh [n (\%)] & $24(32.9 \%)$ \\
Prolene Mesh & $49(67.1 \%)$ \\
Vypro Mesh & \\
\hline
\end{tabular}

Data presented either as [mean $\pm \mathrm{SD}$ (range)] or number (percentage).

Table 2. Data comparing results of two types of mesh.

\begin{tabular}{|c|c|c|c|c|}
\hline Items & $\begin{array}{l}\text { Prolene } \\
\text { Mesh } \\
(n=24)\end{array}$ & $\begin{array}{l}\text { Vypro } \\
\text { Mesh } \\
(n=49)\end{array}$ & $\begin{array}{c}\text { Total } \\
\text { (n) }\end{array}$ & $\begin{array}{l}\text { Signific- } \\
\text { ance } \\
\mathrm{P}<0.05\end{array}$ \\
\hline $\begin{array}{l}\text { Type of Previous Operations } \\
\text { [n (\%)] } \\
\text { Hernia at Trocher Site } \\
\text { (laparoscopy) } \\
\text { Anterior Abdominal Wall Hernia }\end{array}$ & $\begin{array}{r}5(20.8 \%) \\
19(79.2 \%)\end{array}$ & $\begin{array}{r}5(10.2 \%) \\
44(89.8 \%)\end{array}$ & $\begin{array}{l}10(13.7 \%) \\
63(86.3 \%)\end{array}$ & $\mathrm{N} / \mathrm{S}$ \\
\hline $\begin{array}{l}\text { Incision of Previous Operations } \\
{[\mathrm{n}(\%)]} \\
\text { Longitudinal } \\
\text { Transverse }\end{array}$ & $\begin{array}{r}19(79.2 \%) \\
5(20.8 \%)\end{array}$ & $\begin{array}{r}44(89.8 \%) \\
5(10.2 \%)\end{array}$ & $\begin{array}{l}63(86.3 \%) \\
10(13.7 \%)\end{array}$ & $\mathrm{N} / \mathrm{S}$ \\
\hline $\begin{array}{l}\text { Number of Previous Incisional } \\
\text { Hernia Repair } \\
\text { No Previous Repair (Zero) } \\
\text { Once } \\
\text { Twice } \\
\text { Third } \\
\text { Fourth }\end{array}$ & $\begin{array}{c}17(70,8 \%) \\
6(25.0 \%) \\
- \\
- \\
1(4.2 \%)\end{array}$ & $\begin{aligned} 35 & (71.4 \%) \\
11 & (22.4 \%) \\
1 & (2.0 \%) \\
1 & (2.0 \%) \\
1 & (2.0 \%)\end{aligned}$ & $\begin{array}{r}52(71.2 \%) \\
17(23.3 \%) \\
1(1.4 \%) \\
1(1.4 \%) \\
2(2.7 \%)\end{array}$ & $\mathrm{N} / \mathrm{S}$ \\
\hline
\end{tabular}


Table 2. Contd.

\begin{tabular}{|c|c|c|c|c|}
\hline Items & $\begin{array}{c}\text { Prolene } \\
\text { Mesh } \\
(n=24)\end{array}$ & $\begin{array}{c}\text { Vypro } \\
\text { Mesh } \\
(n=49)\end{array}$ & $\begin{array}{c}\text { Total } \\
\text { (n) }\end{array}$ & $\begin{array}{c}\text { Signific- } \\
\text { ance } \\
\mathbf{P}<\mathbf{0 . 0 5}\end{array}$ \\
\hline Complications $[\mathrm{n}(\%)]$ & & & & \multirow{7}{*}{$\mathrm{N} / \mathrm{S}$} \\
\hline No complications & $20(83.3 \%)$ & $48(97.9 \%)$ & $68(93.1 \%)$ & \\
\hline Complications & $4(16.7 \%)$ & $1(2.1 \%)$ & $5(6.8 \%)$ & \\
\hline Recurrence & $2(2.7 \%)$ & - & $2(2.7 \%)$ & \\
\hline Infection Wound & - & $1(2.0 \%)$ & $1(1.4 \%)$ & \\
\hline Sinus Wound & $1(4.2 \%)$ & - & $1(1.4 \%)$ & \\
\hline Pulmonary Embolism & $1(4.2 \%)$ & - & $1(1.4 \%)$ & \\
\hline $\begin{array}{l}\text { Surface Area of Mesh }\left(\mathrm{mm}^{2}\right) \\
{[\text { mean } \pm \mathrm{SD}]}\end{array}$ & $435.0 \pm 331.7$ & $\begin{array}{r}428.8 \\
\pm 323.4 \\
\end{array}$ & & $\mathrm{~N} / \mathrm{S}$ \\
\hline $\begin{array}{l}\text { Duration of Surgery (minutes) } \\
{[\text { mean } \pm \mathrm{SD}]}\end{array}$ & $103.2 \pm 43.8$ & $85.7 \pm 33.7$ & & $\mathrm{~N} / \mathrm{S}$ \\
\hline $\begin{array}{l}\text { Duration of Hospital Stay (days) } \\
{[\text { mean } \pm \mathrm{SD}]}\end{array}$ & $5.4 \pm 3.0$ & $4.8 \pm 3.2$ & & $\mathrm{~N} / \mathrm{S}$ \\
\hline $\begin{array}{l}\text { Duration of Follow-up (months) } \\
\text { Mean Follow-up (months) [mean } \\
\pm \text { SD] }\end{array}$ & $\begin{array}{l}24-60 \\
40 \pm 2\end{array}$ & $\begin{array}{c}9-40 \\
20 \pm 4.5\end{array}$ & & $\mathrm{~N} / \mathrm{S}$ \\
\hline
\end{tabular}

Data either presented as [mean $\pm \mathrm{SD}$ ] or number (percentage).

$\mathrm{N} / \mathrm{S}$ (not significant).

\section{Discussion}

Surgery for incisional hernias has undergone drastic changes in last 20 years. To guarantee good results, special consideration should be given to abdominal wall defect, physiologic changes after chronic incisional hernias and the use of prosthetic material ${ }^{[11-13]}$. In this study, incisional hernia occurs due to previous hernia at trocar site (laparoscopy ports) or open surgery. Most of the incisional hernias reported in this study were due to previous midline compared to transverse incision operations.

Intraperitoneal implantation of meshes were adapted to the physiology of the human abdominal wall to reduce chronic inflammation and adhesions ${ }^{[14-16]}$. Macroporous mesh with pore sizes greater than 100 $\mu \mathrm{m}$ are thought to allow fibrous tissue in-growth, while surrounding synthetic fibers provide reinforcement of abdominal wall ${ }^{[17]}$. Based on law of Laplace and maximum intra-abdominal pressures, Klinge et al. ${ }^{[18]}$ had calculated that mesh with tensile strength of $16 \mathrm{~N} / \mathrm{cm}$ is sufficiently strong for use in repair of abdominal wall hernias. This is thought to represent physiological strength of human abdominal wall and is 
significantly lower than of most meshes ${ }^{[8]}$. Prolene polypropylene mesh, Ethicon, New Jersey, USA) is a monofilament mesh and had pore size of $1.2 \mathrm{~mm}$ and weighing $85 \mathrm{~g} / \mathrm{m}^{2}$. Polyglactin 910 thread (Vypro Mesh, Ethicon, New Jersey, USA) had pore size of $4 \mathrm{~mm}$ and weighing $82 \mathrm{~g} / \mathrm{m}^{2}$ at implantation and $32 \mathrm{~g} / \mathrm{m}^{2}$ after absorption of Polyglactin 910 thread, which usually takes 56-70 days. Long-term studies showed tensile strength of PP implanted in tissue is unchanged over time ${ }^{[19]}$. Dabrowiecki et al. ${ }^{[20]}$ and Bellon et al. ${ }^{[21]}$ found that PP induces intense inflammatory response. Combination of reduced amount of PP with polyglactin multifilament (Vypro mesh) seems to achieve an optimal incorporation $^{[7,22]}$. Mesh with reduced PP material, higher elasticity, larger pores are developed for incisional hernia repair. By adding multifilament Polyglactin 910 to PP mesh, mesh becomes partly absorbable. Nevertheless, reduction of non-resorbable material is limited both by required minimum strength, minimum stiffness necessary for handling by surgeon, particularly during intraoperative placement and fixation $^{[10]}$. In this study, most of the meshes used for incisional hernia repair were vypro (67.1\%).

Mesh can be placed in different sites to strengthen the anterior abdominal wall as prefascial, retromuscular ${ }^{[23]}$, preperitoneal, or premuscular ${ }^{[24]}$, which often requires wide undermining. Intraperitoneal placement technique is straightforward, involves minimum dissection. Proper positioning of prosthesis is important; material must be placed intraperitoneally to overlaps hernia ring by $\geq 3 \mathrm{~cm}$. Failure to superimpose patch over musculoaponeurotic tissue may result in recurrence rates of $4 \%$ to $11 \%$ in cases in which prosthesis is sutured directly to hernia ring ${ }^{[25]}$.

Long-term complications associated with intraperitoneal placement of mesh include adhesions, bowel obstruction, erosion of mesh into viscera, mesh transmigration, recurrence and enterocutaneous fistula ${ }^{[26,27]}$. According to mesh type applied, in this study incidence of complications was non-significantly elevated with Prolene $(6.7 \%)$ versus vypro $(2.1 \%)$. Meanwhile, durations of operation and hospital stay were the same. There were no cases of enterocutaneous fistulae.

Recurrence rate is $2.7 \%$ (2) cases with Prolene mesh due to inadequate mesh size, recurrence developed within the first year. Others reported recurrence after abdominal incisional hernia repair $24 \sim 63 \%$ with 
simple suturing closure ${ }^{[13]}$ and $13 \%-29 \%$ with repair operations using $\operatorname{mesh}^{[13]}$. Previously, it was reported that when hernial orifice is small, there is no difference in recurrence rate between simple closure operation and operative repair with mesh ${ }^{[28-30]}$. The recurrence rate reported in this study was low compared to others, about $70 \%$ of the patients followed for more than two years. Infection rate in this study was $1.4 \%$ with vypro and $1.4 \%$ with Prolene. We had one superficial wound infection treated with antibiotics and dressing. Others ${ }^{[25,31]}$ reported infection rates with mesh repair $(1.7 \%-8 \%)$. It had been previously reported that infection of implant is the most serious complication of intraperitoneal technique ${ }^{[32]}$. Competitive biologic relationships among molecular surface of prosthesis, immune cells surrounding implant, bacteria are important in development of prosthesis infection. Therefore, it is essential to bring prosthesis and tissue into contact to avoid bacterial adhesion which produces infection $^{[32,33]}$, this is probably best accomplished by placing prosthesis in deepest possible position. Pulmonary embolism in this study had been reported to be $1.4 \%$. Cardiac and pulmonary complications must not be overlooked, because they can be result of forceful reintegration of viscera within diminished abdominal cavity ${ }^{[34,35]}$.

\section{Conclusions}

Intraperitoneal implantation of Prolene or vypro mesh is safe, reliable procedure for treatment of incisional hernias with acceptable low incidence of recurrence and complications. The simplicity of technique allows an adequate repair and short operative time. In these series, open mesh repair had excellent results with minimal morbidity and hospital stay.

\section{References}

[1] Luijendijk RW, Hop WC, van den Tol MP, de Lange DC, Braaksma MM, IJzermans JN, Boelhouwer RU, de Vries BC, Salu MK, Wereldsma JC, Bruijninckx CM, Jeekel J. A comparison of suture repair with mesh repair for incisional hernia. $N$ Engl J Med 2000; 343(6): 392-398.

[2] Metzger J, Lutz N, Laidlaw I. Guidelines for inguinal hernia repair in everyday practice. Ann R Coll Surg Engl 2001; 83(3): 209-214.

[3] Luijendijk RW, Lemmen MH, Hop WC, Wereldsma JC. Incisional hernia recurrence following "vest-over-pants" or vertical Mayo repair of primary hernias of the midline. World J Surg 1997; 21(1): 62-66. 
[4] Anthony T, Bergen PC, Kim LT, Henderson M, Fahey T, Rege RV, Turnage RH. Factors affecting recurrence following incisional herniorrhaphy. World J Surg 2000; 24(1): 95-101.

[5] Itani KM, Neumayer L, Reda D, Kim L, Anthony T. Repair of ventral incisional hernia: the design of a randomized trial to compare open and laparoscopic surgical techniques. Am J Surg 2004; 188(6A Suppl): 22S-29S.

[6] Klinge U, Klosterhalfen B, Muller M, Anurov M, Ottinger A, Schumpelick V. Influence of polyglactin-coating on functional and morphological parameters of polypropylene-mesh modifications for abdominal wall repair. Biomaterials 1999; 20(7): 613-623.

[7] Klinge U, Klosterhalfen B, Conze J, Limberg W, Obolenski B, Ottinger AP, Schumpelick V. Modified mesh for hernia repair that is adapted to the physiology of the abdominal wall. Eur J Surg 1998; 164(12): 951-960.

[8] Junge K, Klinge U, Rosch R, Klosterhalfen B, Schumpelick V. Functional and morphologic properties of a modified mesh for inguinal hernia repair. World J Surg 2002; 26(12): 1472-1480.

[9] Klinge U, Junge K, Stumpf M, AP AP, Klosterhalfen B. Functional and morphological evaluation of a low-weight, monofilament polypropylene mesh for hernia repair. $J$ Biomed Mater Res 2002; 63(2): 129-136.

[10] Goldenberg A, Matone J, Marcondes W, Herbella FA, Farah JF. Comparative study of inflammatory response and adhesions formation after fixation of different meshes for inguinal hernia repair in rabbits. Acta Cir Bras 2005; 20(5): 347-352.

[11] Hamy A, Pessaux P, Mucci-Hennekinne S, Radriamananjo S, Regenet N, Arnaud JP. Surgical treatment of large incisional hernias by an intraperitoneal Dacron mesh and an aponeurotic graft. J Am Coll Surg 2003; 196(4): 531-534.

[12] Mudge M, Hughes LE. Incisional hernia: a 10 year prospective study of incidence and attitudes. Br J Surg 1985; 72(1): 70-71.

[13] Koller R, Miholic J, Jakl RJ. Repair of incisional hernias with expanded polytetrafluoroethylene. Eur J Surg 1997; 163(4): 261-266.

[14] Carlson MA, Ludwig KA, Condon RE. Ventral hernia and other complications of 1,000 midline incisions. South Med J 1995; 88(4): 450-453.

[15] Khaira HS, Lall P, Hunter B, Brown JH. Repair of incisional hernias. J R Coll Surg Edinb 2001; 46(1): 39-43.

[16] Kossovksy N, Freiman CJ, Howarth D. "Biomaterial Pathology." Abdominal Wall Hernias. Ed. R. Bendavid, New York: Springer-Verlag, 2001. 221-234.

[17] Amid PK. Classification of biomaterials and their related complications in abdominal wall hernia surgery. Hernia 1997; 1(1): 15-21.

[18] Klinge U, Conze J, Limberg W, Brucker C, Ottinger AP, Schumpelick V. [Pathophysiology of the abdominal wall] Chirurg 1996; 67(3): 229-233.

[19] Postlethwait RW. Long-term comparative study of nonabsorbable sutures. Ann Surg 1970; 171(6): 892-898.

[20] Dabrowiecki S, Svanes K, Lekven J, Grong K. Tissue reaction to polypropylene mesh: a study of oedema, blood flow, and inflammation in the abdominal wall. Eur Surg Res 1991; 23(3-4): 240-249.

[21] Bellon JM, Garcia-Carranza A, Jurado F, Garcia-Honduvilla N, Carrera-San Martin A, Bujan J. Peritoneal regeneration after implant of a composite prosthesis in the abdominal wall. World J Surg 2001; 25(2): 147-152. 
[22] Klosterhalfen B, Klinge U, Schumpelick V. Functional and morphological evaluation of different polypropylene-mesh modifications for abdominal wall repair. Biomaterials 1998; 19(24): 2235-2246.

[23] McLanahan D, King LT, Weems C, Novotney M, Gibson K. Retrorectus prosthetic mesh repair of midline abdominal hernia. Am J Surg 1997; 173(5): 445-449.

[24] Cubertafond P, Sava P, Gainant A, Ugazzi M. [Surgical treatment of postoperative eventration with a prosthetic grid. 62 cases] Chirurgie 1989; 115(1): 66-72.

[25] Gillion JF, Begin GF, Marecos C, Fourtanier G. Expanded polytetrafluoroethylene patches used in the intraperitoneal or extraperitoneal position for repair of incisional hernias of the anterolateral abdominal wall. Am J Surg 1997; 174(1): 16-19.

[26] Leber GE, Garb JL, Alexander AI, Reed WP. Long-term complications associated with prosthetic repair of incisional hernias. Arch Surg 1998; 133(4): 378-382.

[27] Matthews BD, Pratt BL, Pollinger HS, Backus CL, Kercher KW, Sing RF, Heniford BT. Assessment of adhesion formation to intra-abdominal polypropylene mesh and polytetrafluoroethylene mesh. J Surg Res 2003; 114(2): 126-132.

[28] Marchal F, Brunaud L, Sebbag H, Bresler L, Tortuyaux JM, Boissel P. Treatment of incisional hernias by placement of an intraperitoneal prosthesis: a series of 128 patients. Hernia 1999; 3(3): 141-147.

[29] Hesselink VJ, Luijendijk RW, de Wilt JH, Heide R, Jeekel J. An evaluation of risk factors in incisional hernia recurrence. Surg Gynecol Obstet 1993; 176(3): 228-234.

[30] Furukawa K, Taniai N, Suzuki H, Kiyama T, Nomura T, Takahashi T, Yoshiyuki T, Tajiri T. Abdominal incisional hernia repair using the Composix Kugel Patch: two case reports. J Nippon Med Sch 2005; 72(3): 182-186.

[31] Utrera Gonzalez A, de la Portilla de Juan F, Carranza Albarran G. Large incisional hernia repair using intraperitoneal placement of expanded polytetrafluoroethylene. Am J Surg 1999; 177(4): 291-293.

[32] Deysine M, Grimson RC, Soroff HS. Inguinal herniorrhaphy. Reduced morbidity by service standardization. Arch Surg 1991; 126(5): 628-630.

[33] Zieren J, Neuss H, Ablassmaier B, Muller JM. Adhesions after intraperitoneal mesh repair in pigs: Prolene" vs. Vypro". J Laparoendosc Adv Surg Tech A 2002; 12(4): 249-252.

[34] Rives J, Lardennois B, Pire JC, Hibon J. [Large incisional hernias. The importance of flail abdomen and of subsequent respiratory disorders] Chirurgie 1973; 99(8): 547-63.

[35] Stoppa R, Henry X, Canarelli JP, Largueche S, Verhaeghe P, Abet D, Ratsivalaka R. [Indications for selective operative procedures in the treatment of post-operative eventrations of the anterolateral abdominal wall (author's transl)] Chirurgie 1979; 105(4). 
استخدام النسيج الثبكي داخل الصفاق لعلاج الفتاق البطني

\section{فاطمة خنيفس الثبيتي و عدنان مرداد}

قسم جر/حة ، كلية الطب، جامعة الملك عبدالعزبيز

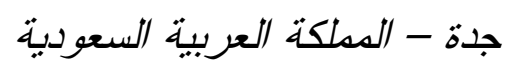

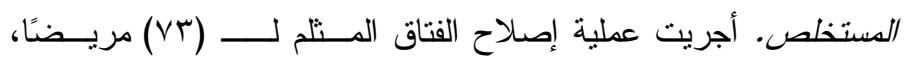

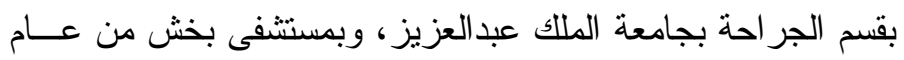

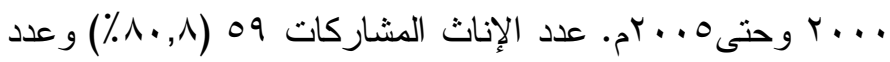

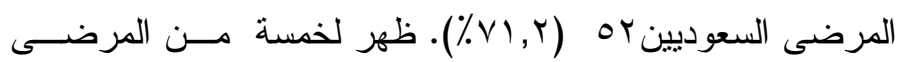

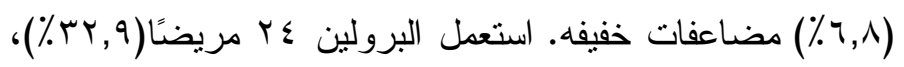

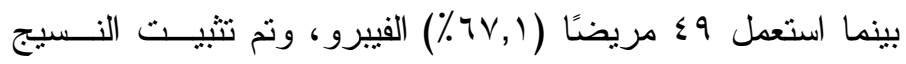

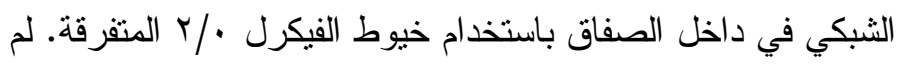

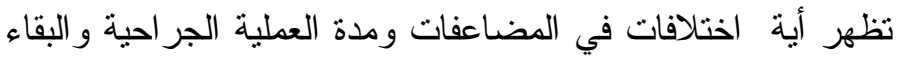

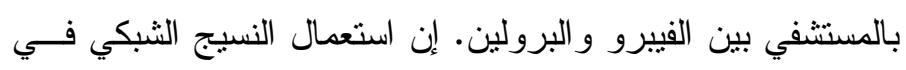

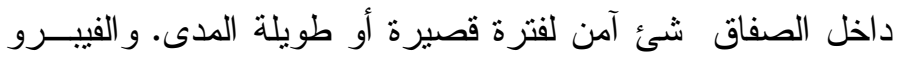

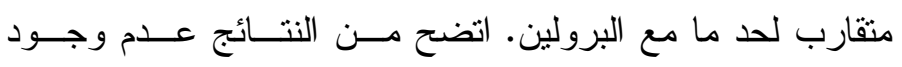

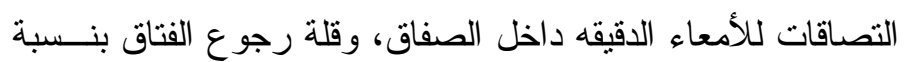
مريضين (Y,Y,\%) على مدى سنة و احدة. 